\title{
Critical thinking skills profile of high school students in learning chemistry
}

\author{
Budi Utami $^{1,}$ Sulistyo Saputro ${ }^{1}$, Ashadi ${ }^{1}$, Mohammad Masykuri ${ }^{1}$, Sri Widoretno ${ }^{1}$ \\ ${ }^{1}$ Science Education Doctoral Program, Faculty of Teacher Training And Education, Sebelas \\ Maret University, Jl. Ir. Sutami 36A Jebres Surakarta, Indonesia \\ Corresponding e-mail: budiutami@staff.uns.ac.id
}

\begin{abstract}
Critical thinking skill is the priority in the goals of education. In this case, the critical thinking has the higher process, such as analyzing, synthesizing, evaluating, drawing conclusion and reflecting which enables the individual to make the reasonable assessment both in the classroom and in the daily life. This research is aimed to determine the students' critical thinking skill in learning Chemistry at senior high school. This research used descriptive method in which the instruments were developed based on the indicators of critical thinking skill. The population of this research was 100 students of tenth, eleventh and twelfth grade from senior high schools in Surakarta which was chosen using cluster random sampling technique. The result of the research shows that the students of tenth, eleventh and twelfth grade have adequate critical thinking skills.
\end{abstract}

\section{Introduction}

Chemistry is the most important discipline which enables the students to comprehend their surroundings. Due to the topics iwhich are related to or based on the material structure, the students find it difficult in learning Chemistry. Chemsitry curriculum generally combines numerous abstract concepts in which they are the center of learning Chemistry and any other disciplines [1]. These concepts are essential because advanced chemistry or science concept or science theory are not easy to be understood if the underlying concepts are not really understandable for the students ([2], [3], [4], [5]). The abstracts characteristics in Chemistry along with the difficulties in other learning content (i.e. Mathematics characteristics from numerous chemical content) means that Chemistry learning needs the higher level of critical thinking skill [6]. One of the important characteristics in Chemistry is the constant interaction between macroscopic and microscopic level of thinking in which it is the aspect in Chemistry or Physics learning that becomes the significant challenge for beginners [7]. The characteristic of Chemistry is conceptual which is frequently obtained from the rote learning (reflected from recall which is efficient for the exam). The understanding requires the conceptual comprehension using the meaningful way. Therefore, the students show several proofs about their learning and comprehension in their answer sheet and the researcher found the misunderstandings, namely learning to memorize and certain parts in basic Chemistry which they have not understood in each level [8].

It is vital for the teacher to know what the learners have already known and how they came to acquire the knowledge. Many students come to a class with wrong ideas, 
confused ideas or even a complete lack of background knowledge. Learning experiences need to be offered to prepare the students to grasp new material by clarifying or correcting previously held concepts or by providing fundamental instruction on such concepts [9].

Critical thinking has been singled out as one of the most important skills for citizens of the twenty first Century [10]. The process of critical thinking is not merely reflecting, drawing conclusion, and synthesizing information, but it also enables the indiviual to make the reasonable assessment both in classroom and in the daily life. Clearly, students need critical thinking in their academic life. They need to solve word problems in math class, to conduct scientific inquiry in chemistry, to understand the workings of the human mind in psychology, and to write paragraphs, essays, and term papers across the curriculum. All of these assignments require them to think critically. Ultimately, however, teachers want students not only to practice these skills in the classroom but to take them out into the world and use them [11]. Holma has pointed out, it is not enough for students to have critical thinking skills; they also need to use these skills effectively [12]. Thus, critical thinking always involves both the essential skills or abilities and the disposition to use them.

The students need to comprehend that critical approach development is important to be the skillful employees who are able to adapt with the new work situation [13]. Critical thinking is crucial to achieving this outcome and is seen by some as the trademark of a well-educated person and as important for becoming an active and engaged employee and global citizen [14]. Thomas [15] proposes that critical thinking can and should be developed from the first year of university in order for students to cope with their future studies and to be of most use to future employers. In a time when individuals are required to make decisions more frequently than ever, critical thinking has become a widely recognized learning outcome of college students [16]. Now a day experts in education and development agree that critical thinking not only has to be one of the goals of education and development, but also an inseparable part of education at any level; because, critical thinking is a kind of thinking that analyzes, evaluates and selects and provides the best solution for humans, what is the necessity for today's world.

The researcher has found that the teachers frequently asked about the cognitive questions. The questions should be designed to promote the evaluation and the synthesis of the fact and concept [17]. Halpern [18] arranges his own taxonomy based on the critical thinking including: (a) verbal logical thinking; (b) argument analysis skill; (c) thinking skill in testing the hypothesis; (d) possibility and possibility and uncertainty; (e) decision making and problem solving skill.

Researchers have found that often teachers ask questions cognitive level significantly lower than of the higher level questions. Generally, critical thinking skills refer to the abilities to analyze, synthesize, and evaluate information as well as the disposition to apply these abilities (Halpern, 2001). Scriven and Paul begin to define critical thinking as "the intellectually disciplined process of actively and skillfully conceptualizing, applying, analyzing, synthesizing, and/or evaluating information gathered from, or 
generated by, observation, experience, reflection, reasoning, or communication, as a guide to belief and action. In the view of psychology, critical thinking is considered a skill and it is focuses on the thought process. Some psychologists refer to the classification by Bloom for defining critical thinking and place critical thinking among the thinking skills of Bloom [18].

Bloom [19] offered one of the first comprehensive elaborations of these important skills. The Bloom Taxonomy is a hierarchy of thinking skills that ranges from simple skills, such as knowledge, to complex thinking, such as evaluation ([20]. [14]. [13], [21], [22]). Since the conception of Bloom's Taxonomy, his colleagues [27] have carried on his work and developed a two-dimensional taxonomy for learning, teaching, and assessing student learning outcomes. The Knowledge Dimension identifies four types of knowledge: factual, conceptual, procedural, and metacognitive. The second aspect of Bloom's Taxonomy, the Cognitive Process Dimension, outlines six ways of thinking (remember, understand, apply, analyze, evaluate, and create) and their many sub processes. Moreover, these are among the core processes or skills that are the basis of any discussion of critical thinking. The initial words used in the question, students can be challenged at different levels of cognition. Higher-level thinking questions should start or end with words or phrases such as, "explain," "compare," "why," "which is a solution to the problem," "what is the best and why," and "do you agree or disagree with this statement?', For example, a student could be asked to compare the use of parachlorophenylalanine versus serotonin for control of post-treatment soreness [21].

The example of words that can be used to begin questions to challenge at the different levels of the Bloom Taxonomy are given in Table 1.

Table 1. Examples of Questions

\begin{tabular}{|c|c|c|}
\hline Category & Key Concepts & Examples \\
\hline Knowledge & Memorization, description & $\begin{array}{l}\text { What, when, who, define, } \\
\text { describe, identify, state, } \\
\text { show, how }\end{array}$ \\
\hline Comprehension & Explanation, comparison & $\begin{array}{l}\text { Conclude, demonstrate, } \\
\text { rephrase, differentiate, } \\
\text { explain, give an example of }\end{array}$ \\
\hline Application & Solution, application & $\begin{array}{l}\text { Build, construct, solve, } \\
\text { test, demonstrate, how } \\
\text { would you }\end{array}$ \\
\hline Analysis & $\begin{array}{l}\text { Induction, deduction, } \\
\text { logical order }\end{array}$ & $\begin{array}{l}\text { Support your, what } \\
\text { assumptions, what reasons, } \\
\text { does the evidence } \\
\text { support the conclusion, } \\
\text { what behaviors }\end{array}$ \\
\hline Synthesis & Productive thinking & $\begin{array}{l}\text { Think of a way, propose a } \\
\text { plan, develop, suggest, }\end{array}$ \\
\hline
\end{tabular}




\begin{tabular}{ll}
\hline & formulate a solution \\
\hline Evaluation & Choose, evaluate, decide, \\
& defend, what is the most \\
& appropriate, which would \\
& you consider \\
\hline
\end{tabular}

Educators can use various instructional methods to promote Critical Thinking and problem solving. Although educators value a student who thinks critically about concepts, the spirit or disposition to think critically is unfortunately, not always present in all students. Many college faculties expect their students to think critically [21]. Teaching problem-based learning is an effective learning strategy which encourages the students by strengthening critical thinking for attainment of the skill to solve problems. Problem solving is considered as a mental activity that leads to the acquirement of new knowledge and skills [23].

\section{Method}

The population of this research was 100 students of tenth, eleventh and twelfth grade from senior high schools which was located in Boyolali, Karanganyar, Sukoharjo and Surakarta, Central Java, Indonesia, which was chosen using cluster random sampling technique. There are three senior high schools in The studies have been carried out in Januari to July 2016. This research uses descriptive method. The instruments were developed based on the indicators of critical thinking skill. The instruments are ten multiple choice questions, each answer choice has a different answer scores start form one to four.

\section{Result and Discussion}

In this research, the students answered the questions which were developed based on the critical thinking indicators, namely: 1) Differentiating the fact, non fact and opinion, 2) Differentiating certain and uncertain conclusion based on the observation and statement, 3) Testing the trustworthiness of the statements, 4) Differentiating the relevant and irrelevant information, 5) Identifying cause and effect, 6) Considering another point of view, 7) Thinking critically about what is read. The example for multiple choice question is shown at Table 2 .

Table 2. The example for multiple choice question

\begin{tabular}{|c|c|c|c|c|}
\hline $\begin{array}{c}\text { Critical } \\
\text { Thinking } \\
\text { Components }\end{array}$ & $\begin{array}{l}\text { Critical } \\
\text { Thinking } \\
\text { Indicators }\end{array}$ & Question Indicators & Questions & $\begin{array}{l}\text { Answer Key } \\
\text { and Score }\end{array}$ \\
\hline $\begin{array}{l}\text { Differentiati } \\
\text { ng the fact, } \\
\text { non-fact and } \\
\text { opinion. }\end{array}$ & $\begin{array}{l}\text { Choosing the } \\
\text { statement } \\
\text { which is } \\
\text { included into } \\
\text { opinion. }\end{array}$ & $\begin{array}{l}\text { The students are } \\
\text { given several } \\
\text { statements and they } \\
\text { choose the statment } \\
\text { which is included } \\
\text { into opinion. }\end{array}$ & $\begin{array}{l}\text { Which of the following } \\
\text { statement that is included } \\
\text { into opinion? } \\
\text { A. I dream that I get D in } \\
\text { Chemistry examination } \\
\text { and it becomes real. If I }\end{array}$ & $\begin{array}{l}\text { Answer A : Score } 4 \\
\text { Answer B : Score } 1 \\
\text { Answer C : Score } 3 \\
\text { Answer D : Score } 2\end{array}$ \\
\hline
\end{tabular}




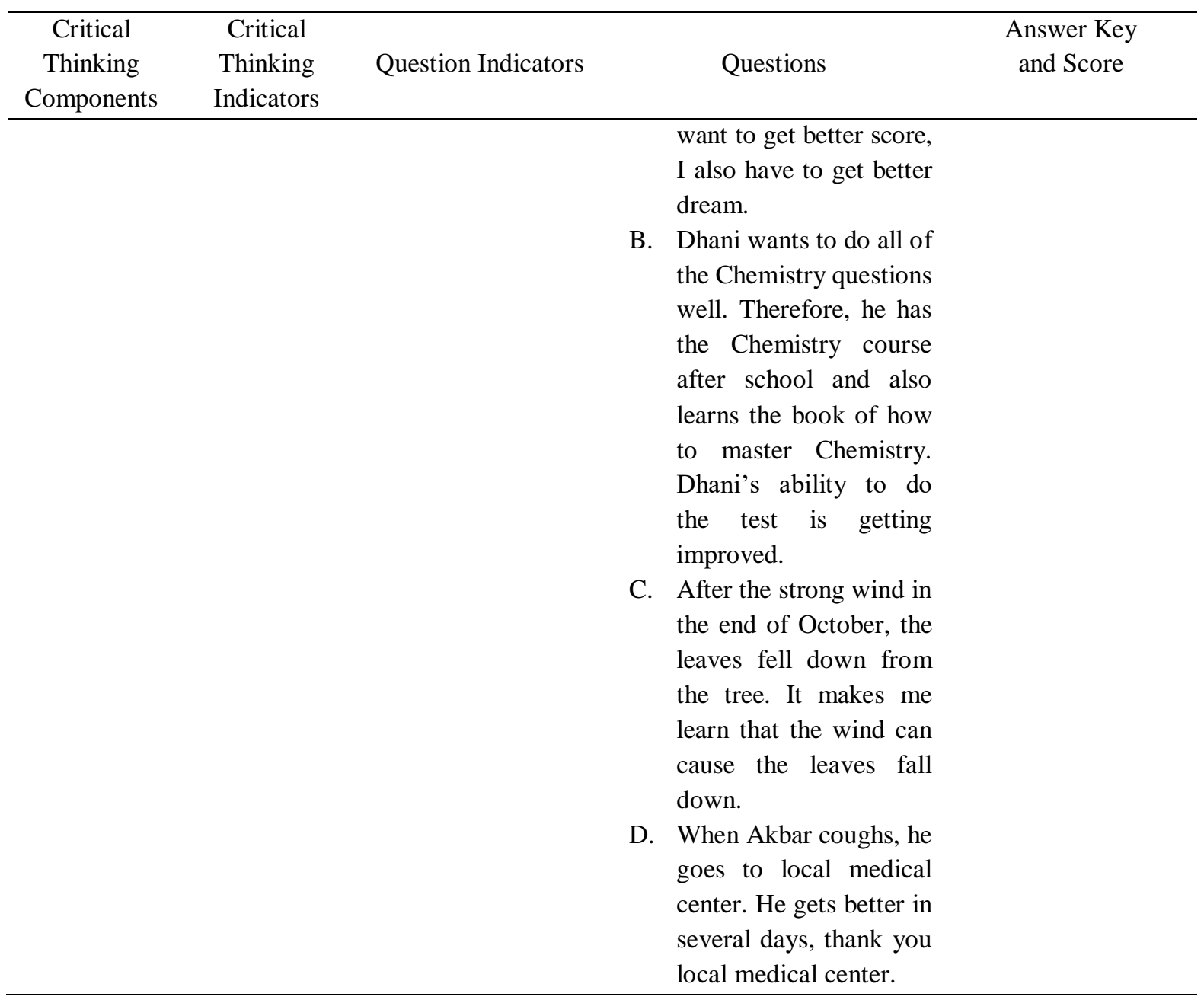

The result of 100 students doing the critical thinking questions can be seen in the Table 3.

Table 3. Percentage of Students' Critical Thinking Skill in Senior High School

\begin{tabular}{|c|c|c|c|}
\hline \multirow[t]{2}{*}{ Class } & \multicolumn{3}{|c|}{ Percentage of Students' Critical Thinking Skill } \\
\hline & Low & Medium & High \\
\hline $\mathrm{X}$ & 11 & 71 & 18 \\
\hline XI & 26 & 68 & 6 \\
\hline XII & 18 & 82 & 0 \\
\hline
\end{tabular}

Based on Table 3, it can be seen that the students' critical thinking skills in the $10^{\text {th }}$, $11^{\text {th }}, 12^{\text {th }}$ grade students of senior high schools have adequate critical thinking skills. Difficulties Chemistry teacher in the learning process of cognitive assessment on the level of analysis, synthesis and evaluation. Due to the method used by the teacher which has not developed the students' critical thinking skill [26]. Indicators of critical thinking skills deciding most situations requiring problem solving achieving the highest average score. Given some of the statements, students can choose the statement that need solving problems. Indicators of critical thinking skills given some statement, students can determine the priority issues to reach an average lowest score. 
The study from the Commission on Teacher Credentialing in California and the Center for Critical Thinking at Sonoma State University initiated a study of college and university faculty throughout California to assess current teaching practices and knowledge of critical thinking [24]. They found that although 89 percent of the faculty survey claimed that critical thinking is a primary objective in their courses, only 19 percent could explain what critical thinking is, and only 9 percent of these faculties were teaching critical thinking in any apparent way. This observation is supported by evidence from other sources more specific to the sciences, which suggest that many introductory science, technology, engineering, and math (STEM) courses do not encourage the development of critical thinking abilities [25]. The teachers have not assessed to the cognitive skill in the level of analyzing, synthesizing and evaluating [26].

Regardless of the methods used to promote critical thinking, it must be taken into account to consider many factors that may inhibit a student from thinking critically. The student's disposition to think critically is a major factor, and if a deficit in a disposition is noticed, this should be nurtured. Students should be encouraged to be inquisitive, ask questions, and not believe and accept everything they are told. As pointed out by Loving and Wilson and Oermann, thought develops with practice and evaluation over time using multiple strategies. Additionally, faculty should be aware of their course goals and learning objectives. If these goals and objectives are stated as higher as thought outcomes, then activities that promote critical thinking should be included in classroom activities and assignments [21]. Finally, it is important that critical thinking skills should be encouraged and reinforced in all classes by teaching in the faculty, not only at the college level but at every level of education. Although huge gains in critical thinking may not be reflected in all college students, we can still plant the seed and encourage students to use their thinking abilities in order to make them grow over time.

\section{Conclusion}

The students' critical thinking skills in the $10^{\text {th }}, 11^{\text {th }}, 12^{\text {th }}$ grade students of senior high schools have adequate critical thinking skills. The school should be aware of their course goals and learning objectives. If these goals and objectives are stated as higher as thought outcomes, then activities that promote critical thinking should be included in classroom activities and assignments.

\section{Reference}

[1] Taber, K. S. 2002. The Royal Society of Chemistry.

[2] Zoller, U. 1990. Journal of Research in Science Teaching, 27(10), 1053-1065.

[3] Nakhleh, M., 1992. Journal of Chemical Education, 69(3), 191-196

[4] Ayas, A. \& Demirbas, A. 1997. Journal of Chemical Education, 74(5), 518-521.

[5] Nicoll, G. 2001. International Journal of Science Education, 23(7), 707-730.

[6] Fensham, P., 1988. Development and Dilemmas in Science Education. 5th 
Edition. London: Falmer.

[7] Bradley, J. D. \& Brand, M., 1985. Journal of Chemical Education, 62(4), p. 318.

[8] Johnstone, A.H., 1984. Journal of Chemical Education, 61(10), 847-849.

[9] Sirhan, G. 2007. Learning Difficulties in Chemistry: An Overview. Turkish Science Education. Volume 4, Issue 2, September 2007

[10] Halpern, D. F. 2014 Thought and Knowledge. Fifth edition. NY: Psychology Press.

[11] Beaumont, J. 2010. TESOL Journal, 1.4, 1-22.

[12] Holma, K. 2014. Under review. ojs.statsbiblioteket.dk/index.php/spf/article/download/18280/20109

[13] Forrester, J. 2008. Asian Sosial Science, 4(5), 100-105.

[14] Facione, P. A

A. 2010 . http://www.insightassessment.com/pdf_files/what\&why2006.pdf.

[15] Thomas, T. 2011. Asian Social Science, 7. No. 4, 26-33.

[16] Halpern, D. F. 2001. The Journal of General Education, 50 (4), 238-254.

[17] Magno, C. 2010. The role of metacognitive skills in developing critical thinking. Metacognition Learning (2010) 5:137-156. Springer Science Business Media, LLC 2010

[18] Halpern, D. F. 1998. Teaching Critical Thinking For Transfer Across Domain. American Psychologyst Assosiation. Vol 53, No.4.449-455.

[19] Bloom, B.S. 1956. Taxonomy Of Educational Objectives Handbook 1 Cognitive Domain. Addison Wesley Publishing Company.

[20] Walker, S. E. (2003). Journal Of Athletic Training, 38(3), 263-267.

[21] Duron, R; Limbach, B; Waugh, W. 2006. International Journal of Teaching and Learning in Higher Education, 17 ( 2), 160-166.

[22] Scott, Sophia. 2008. Journal of Technology Studies; Spring 2009, Vol. 34 Issue 1, p39.

[23] Yuan, M.H., Kunaviktikul,W., Klunklin,A., Williams, B.A. 2008. Nursing and Health Sciences (2008), 10, 70-76

[24] Scriven, M. and Paul, R. 1987. National Council for Excellence in Critical Thinking. http://www.criticalthinking.org/pages/defining-critical-thinking/766

[25] Handelsman J, et al. 2004. Science 304: 521-522.

[26] Utami, B; Saputro, S; Ashadi; Masykuri, M; Aminah, S. N. 2016. International Conference on Educational Research and Evaluation (ICERE). ISSN: $2407-$ 1501

[27] Anderson, L. W. 2001. A Taxonomy for Learning, Teaching and Assesing, A Revision of Bloom's Taxonomy of Educational Objectives. New York: White Plains. 